\title{
THE ROLE OF ISLAMIC PUBLIC FINANCE INSTITUTION IN THE SOCIETAL ECONOMIC EMPOWERMENT
}

\author{
By Rahmani Timorita Yulianti*
}

\section{Abstract}

The article discusses the role of public Islamic finance institution viewed in the context of economic public endeavor. This problem emerges in public because the public Islamic finance institution in Indonesia does not take in part proportionally yet to create public prosperity in Indonesia whereas the research of the Language and Literature Center in UIN Syarif Hidayatullah and Ford Foundation results that the potential of funds (Zakat, Infak, Shodaqoh) and donation of Moslems in Indonesia (IDR 19.3 billions) managed by the public Islamic finance institution can be used for people prosperity. Besides, it is supported with the big number of Moslems in Indonesia. Therefore, there are two important things to be focused on this article. First, Why has the fund in the Islamic Public Finance Institution such as ZIS and endowment in Indonesia not played optimal yet in creating social welfare? Then, how to empower the public finance institution in Indonesia?

ò หôn

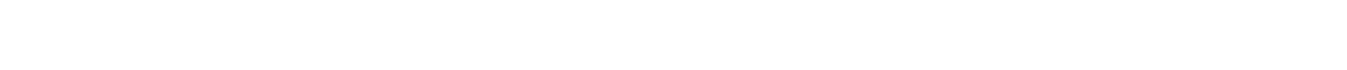

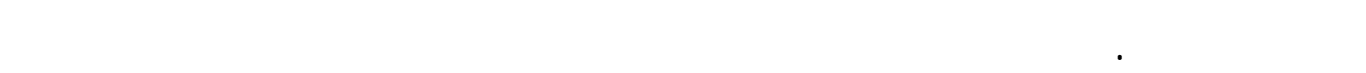

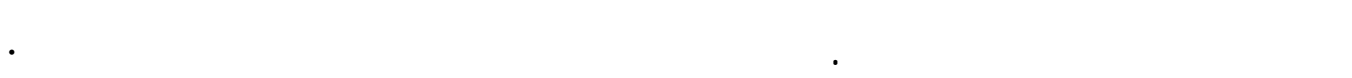

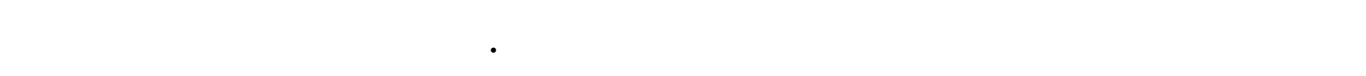

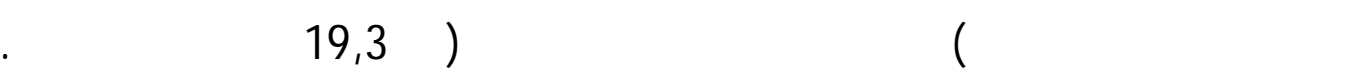

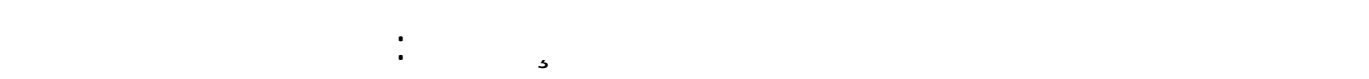

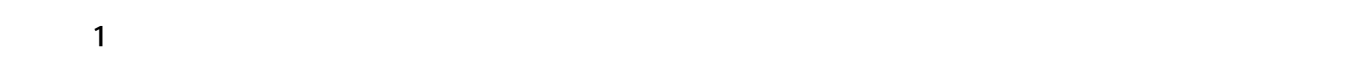

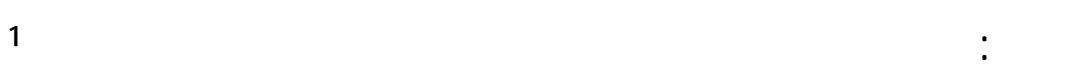

Keywords: donation, alms, Indonesia, charity

\section{A. Introduction}

Indonesian people are forced to think very hard in the middle of their difficult economic life as the price of BBM (fuel) has increased. The goods prices are increasing, primary need is soared, and meanwhile people's income is not 
proportional to the primary necessity level. Even there are many Pemutusan Hubungan Kerja, PHK (deposition) enormously. ${ }^{1}$ This condition causes the number of poor population in Indonesia to increase. The Indonesian Statistic Centre defines poverty as disability to fulfill minimum life need standard including food, outfit, house, health, education, transportation and other several things and services. ${ }^{2}$ The population of poor in Indonesia has increased since $2001{ }^{3}$ The economic crisis in 1998 raised the number of poor people to 24,23 percent. In 2006, the population of poor people decreased into 17,8 percent. However, this number was still larger than the number of poor people in 2005 (16\%). In the village, poverty is larger because the ownership of production land is getting narrower. This causes hidden unemployment or gives birth to new labor in the agriculture, raising the developing poverty seed. $^{4}$

From this data Indonesian people where Muslim is the majority are invited to dig economic and financial source thought based on Islamic values and teachings. Islam, as moral religion, is presently challenged not only to break unbalance social structure, but also has a will to create social welfare. Islam is not as a religion with elitist normative values which does not have social concern, but it integrally pretenses to actively participate in the problem of social community. Furthermore, Islam is also a just religion. This is due to the fact that Islam has the concept of social justice as dissolved in its doctrines. Therefore, in the context of Indonesian society, unserious ness to handle the destiny and future of millions dhuafa' people which are spread

\footnotetext{
* Lecturer of FIAI UII Yogyakarta, now is taking S3 program of Islamic Economics at UIN Sunan Kalijaga Yogyakarta. E mail: rahmani_ty@yahoo.com

1"Wakaf Produktif: Sebuah Alternatif Untuk Pemberdayaan Umat" http://www.pkpu.or.id/artikel.lite.php?id=10\&no=16/accessed on 17 Oktober 2007 10:46:11 GMT.

${ }^{2}$ Based on Data Badan Pusat Statistik in 1999 in Edy Suandi Hamid, Ekonomi Indonesia: Dari Sentralisasi ke Desentralisasi, (Yogyakarta: UII Press, 2005), pp. 92-93.

3 According to Data dan Informasi Badan Pusat Statistik in 2003, poor population of Indonesia in 2001 was 35,952 millions, in 2002 was 38,394 million and in 2003 was 37,339 millions, see Edy Suandi Hamid, 2006, Ekonomi Indonesia....p. 96.

${ }^{4}$ As quoted at http://yudhitc.wordpress.com/2007/06/19/sosial-kompas-yudhit-ciphardian/ recorded on 18 November 2007 13:26:52 GMT.
} 
throughout the nation is a contrast attitude to the spirit and commitment of Islam towards human solidarity and social welfare.

In this case, there are several Islamic financial instruments to guarantee welfare that are managed by Islamic Public Finance Institution. Among Islamic financial system, there is an obligation (must be applied) such as zakat and some others are recommendation such as infak, sedekah and wakaf. Some Islamic financial systems nowadays are encouraged by Muslim community in the whole wide world. But Indonesia as a country with the biggest Muslim community, distributing zakat, infak, sedekah and wakaf is not implemented yet as expected, whereas Indonesia has had regulations on zakat. ${ }^{5}$

Besides that, based on the research result conducted by Language and Culture Centre (PBB) of UIN Syarif Hidayatullah and Ford Foundation, the potential funds of ZIS (Zakat, Infak, Sedekah) and wakaf of Muslim in Indonesia can be used for the sake of social welfare which is up to IDR 19,3 billions. While in the form of goods is IDR 5,1 billions and money is IDR 14,2 billions. That large number of fund, two third of them is still from Zakat Fitrah (IDR 6,2 billions) and the rest is from property zakat IDR 13,1 billion. ${ }^{6}$

From the condition it shows that Islamic Financial system in this case is the public fund management by Islamic Public Finance Institution in which the philanthropy of Islam commonly including Zakat, Infak and Sedekah (ZIS) institution, and wakaf, has not capable optimally yet to play its role as financial source to develop Indonesian social welfare, whereas fund potential of ZIS and wakaf is likely to be applied.

From the above explanation, some problems that need solution can be asked. The problems are as follows:

5 Republika, 2003, "Potensi Zakat Masyarakat Belum Tergali”, Friday, 11 July 2003, http://www.halalguide.info/content/view/430/46/ accessed on 23 October 2007 09:19:43 GMT.

6 Azyumardi Azra, "Diskursus Filantropi Islam dan Civil Society", in Berderma Untuk Semua: Wacana dan Praktik Filantropi Islam, (Jakarta: PBB, Ford Foundation, and Teraju, 2003) p. xxiii. See also Research result of PBB, UIN Syarif Hidayatullah dan Ford Foundation, 2003, Philantropi Untuk Keadilan Sosial: Studi Kasus Masyarakat Muslim Indonesia. 
1. Why has the fund in the Islamic Public Finance Institution such as ZIS and wakaf in Indonesia not played optimal yet in creating social welfare?

2. How to empower Islamic Public Finance Institution in Indonesia?

To ease answering the problems above, this study employs positivistic paradigm called social fact paradigm. In this paradigm, a social phenomenon is understood as natural phenomenon so that this study aims at explaining why does an event occur? ${ }^{7}$ In this case is the social fact that the role of Islamic Public Finance Institution that manages ZIS and wakaf fund in creating social welfare in Indonesia has not optimal yet.

Meanwhile, to formulate Islamic Public Finance Institution empowerment in Indonesia, contextualization analysis method is used, that is contextual meaningfulness treat similarly by seeing the interrelationship between past, present and the future. ${ }^{8}$ Here the writer describes relationship phenomenon of Islamic Public Finance Institution managed by ZIA and wakaf funding within past historical meaning, present functional meaning and predict or anticipate the future meaning.

\section{B. The Role of Islamic Public Finance Institution in Creating The Welfare}

Social welfare system that rooted in the Islamic welfare effort is part of our agenda that come to color the interaction between Islam and state in Indonesia. The accommodation process of the state to Islamic social welfare system started to be strong in the end of new era (Orde Baru) government with the effectiveness of UU no. 38/1999 about zakat management. This regulation becomes law foundation that put Islamic social welfare system as a very important part of policy and social welfare system in Indonesia.

Indonesian Moslem movement for putting Islamic social welfare system into national welfare system has special characteristic compared to other Moslem

\footnotetext{
${ }^{7}$ Imam Suprayogo dan Tobroni, Metodologi Penelitian Sosial Agama, 2nd edition, (Bandung: PT Remaja Rosdakarya, 2003), pp. 92-93.

${ }^{8}$ Noeng Muhajir, Metodologi Penelitian Kualitatif, 3rd edition, (Yogyakarta: Rake Sarasin, 1998), p. 178.
} 
countries. If in countries such as Pakistan, Sudan, United Emirate Arab and Malaysia, imagination about Islamic economic system is very influential, this can not be found in Indonesia. Islamic economic shift, the desire to implement Islam as the state ideology is a foundation to put zakat fund management under state responsibility. It is not surprising that in Indonesia Islamic social welfare system, zakat often serves as one central issue of the politic tensions between Islam and the state.

Based on the research result done by PBB of UIN and Ford Foundation (FF) some interesting facts are found. One of them is that Indonesian Moslem society has high level of generosity and it is based on spiritual motivation, while their social motivation is still low. ${ }^{9}$ From this case study it is commonly found that religious authority still very strongly legitimates discourse and practice of ZIS and wakaf payment. It means that Moslem society in Indonesia is strongly affected by religious motives and aims that are understood in the frame of submission to religious doctrines based on classic interpretation of donation teaching. Giving donation is part of worship and may lead the giver to be close to Allah. One of the roots of the problem is the formalization of zakat.

It means that zakat is only considered as normative obligation, ${ }^{10}$ without paying attention to its effects on the community economic empowerment. The effect is that economic fair spirit in implementing zakat is lost. Zakat orientation is not directed to social economic empowerment, but it is just as an obligation from God. Even, it is not few of Muzakki who pay zakat with the purpose to purify their property or in order that their wealth is blessing (berkah). This means that muzakki pays zakat

\footnotetext{
${ }^{9}$ Research Result of PBB UIN Syarif Hidayatullah and Ford Foundation in 2003, Philantropi Untuk Keadilan Sosial: Studi Kasus Masyarakata Muslim Indonesia.

${ }^{10}$ QS. Al-Taubah (9) 60 which means: Assadaqat (it means zakat) are only for the fuqara (poor) and al masakin (the needy) and those employed to collect (the funds) and to attract the heart of those who have been inclined (towards Islam) and to free the captives and for those in dept and for Allah's cause (for muhidun those finghting in a holy battle) and for the way farer (a traveler who is cut off from everything) a duty imposed by Allah, and Allah is All Knower, All-Wise.
} 
to his own needs. It is not wrong, but the substance of zakat command and its effect to social economic becomes ignored. ${ }^{11}$

Nevertheless, there is a positive perception on the concept of social justice to create welfare. However, this social justice paradigm is not commonly integrated yet in the concept or practice of religion in ZIS and wakaf payment in Indonesia.

What needs to do now is dissemination process that social motivation should be focused more on spiritual motivation base. While the mobilization of ZIS and wakaf funds through Islamic Public Finance Institution or ZIS organization is blocked with the fact that the society still glorify the principle of secrecy in giving contribution, and still doubt the trust from the Islamic Public Finance Institution or ZIS organization. While, ZIS distribution still orients at charity or social that can not be developed for productive activity in empowering social economy. In the other word, fund distribution in Islamic Public Finance Institution to the purpose of social welfare establishment has not played its optimal role yet or is still very weak.

Fund distribution model which does not put economic and social map also become the reflection of loosing economic social justice spirit in zakat. There is not few muzakki who give their zakat directly to poor people without paying attention that whether the fund may increase their level of welfare or not. Muzakki may only think about the law, that it is enough for them to pay zakat, so that his obligation as Moslem is done. Here is the important of amil in the process of zakat distribution. Professional amil institution is needed very much so fundraising process and its distribution can be done effectively and efficiently. To make it effective and efficient one of them is by making social economic mapping. The difficulty is that sometimes

${ }^{11}$ QS. Al-Baqarah: 177 which means: it is not al-birr (piety righteousness and each and every act of obedience to Allah) that you turn your face towards the East of the West but all birr is the quality of the one who believes in Allah, the last day, the angels, the book, the prophets and gives wealth in spite of love for it to the kinsfolk, to the orphan and to the masakin (the needy) and to the wayfarer and to those who ask and to set slaves free and performs as-solat and gives the zakat...see also QS. Ali Imran: 92 which means: by no means shall you attain al-birr (peity righteousness) here it means Allah rewad, paradise unless you spend in Allah's cause of that with you love and whatever of good you spend, Allah knows it well. 
people considered amil as zakat collection post, without optimal working demand for fundraising and professional fund distribution pattern.

In relation to strengthening this amil position, professionalism development of zakat institution is the key factor. This professionalism includes proactive effort in fundraising with two aims: increasing zakat fun income and increasing the number of people who are aware of paying zakat. Including in the zakat institution professionalism is optimizing zakat fund management for economic empowerment and real sector development. Therefore, zakat institution needs to have a good social economic mapping, so that zakat fund will come to its target. Besides, the model of productive zakat fund distribution must orient more to zakat institution than consumptive fund distribution patterns.

By paying attention to the matters above, zakat will be more beneficial for the welfare and productivity of wide society. It is the right time to manage zakat fund through prophetic mission which was brought by the Prophet, that is justice mission of economic distribution and minimize fund concentration only to a certain elite group. Maybe the state is not capable to free itself from global economic monsters. However, with the teaching of Muhammad, Islam community can inspire government in this country how to stand on our own feet and free Indonesian economy from neo imperialism of capitalist countries. One of them is through professional zakat management to reach social welfare. ${ }^{12}$

In accordance with the discussion above, if we trace in the economic literature, it is found that the term of "welfare" has several meanings. The definition of "welfare" in the economic system of conventional capitalist is a pure materialist concept that denies spiritual relationship. The concept of "welfare" which puts humanity and spiritual aims surely will cause the need of discussing, based on economic knowledge, what is the essential of the welfare aim and how to implement

12 Dani Muhtada, Rekonseptualisasi Zakat Untuk Keadilan, a coordinator of Amil Zakat institution MIIAS (Masyarakat Islam Australia Selatan) 2006-2007, Candidate Doktor, AusAID fellow in Flinders University Australia on http://www.rumahzakat.org/detail.php?id=3772/ accessed on 21 November 2007 17:32:36 GMT. 
it. The purposes of two welfare concept in the two visions do not only include economic welfare in the form of material, but also including human brotherhood problem and social-economic justice, life purity, individual honor, property honor, peaceful mind and happiness, as well as the harmony of family and society life.

The welfare concept of the inner self and outer world can be said has implemented already if some following elements have been fulfilled, such as primary need of the society has been fulfilled, the different level of social economic is not obvious, full employment (these is no unemployment for productive age), justice in distributing income and wealth, economic stability is reached without overseas loan burden, the inflation level is not high, decreasing of non renewable economic resource is not high, and ecosystem which may endanger life does not occur.

Beside all the matters above, the following matter must be fulfilled too, that is the realization of high level of family and social solidarity to the collective responsibility between government and society towards children, old people, sick people, weak people, poor people, broken family, widows, preventing juvenile delinquency, crimes, social chaos and racial fight.

To reach the concept of welfare above, everybody as a society member or business world, or as part of government organization must sacrifice personal interest for fulfilling social benefit in the circle of family, business world, social life, or in the government. As long as maximal wealth and consumption are the only aim, then sacrifice will be nothing. ${ }^{13}$

Although the opportunity to play greater role in the future, however we are generally not sure yet to the capability of Islamic public finance institution in responding social problem effectively because it limitation of capacity in compare to a very complex social problem. From several institutions, it is found some matters

13 According to Al Ghazali welfare (Maslahah) of a society depends on livelihood and maintenance of five basic goals such as, religion, life/spirit, family/descendent, wealth/property, and intellectual/intelligent. He emphasis that welfare in appropriate to divine guide is goodness of the world and hereafter, see Adiwarman A. Karim, Ekonomi Mikro Islami, edisi $3^{\text {rd }}$, (Jakarta: PT Raja Gravindo Persada, 2007). 
which become basic weakness such as the low of human resource and the low of organization and management capacity. Uninstitutionalization of standard public responsibility mechanic also becomes common phenomenon of Islamic public finance institution.

This limitation is based on the reality that Islamic public finance institution has not had strong institutional tradition. Islamic public finance institution culture, otherwise, still relies on inter-personal and individual capacity relation, whereas the substance role of Islamic public finance institution to empower social economy orients more to strengthen the institution and system. In the concept of Islamic public finance institution for welfare, the resource collected aim at supporting activity that leads to social change. The change can only be done by social organizational strategy, advocacy and good public education. Therefore, personal culture of Islamic public finance institution can not be relied on to do those duties.

This construct of Islamic public finance institution shaped because of the strong doctrine influence. In Islam, doctrine gives wide space to individual freedom in applying donation. From the early of Islam, zakat, infak and sedekah (ZIS) are paid directly by muzakki to mustahik, and others are collected by Mosque management and religious figure. This donation pattern is relevant with the social structure when this pattern is credible enough in the eyes of the society. However, in Islam personal accountability may get strong resonance in the doctrine. This reality may likely answer the question why Islam generosity does not appear in the strong institution form so that it is needed to be responded systemically by strong Islamic public finance institution.

\section{The Empowerment of Islamic Public Finance Institution in Indonesia}

Historically, it can be known that the role of the Prophet, Abu Bakar, Umar bin Abdul Aziz got and developed zakat fund to increase social welfare. The policy in zakat as income source for direct cross subsidy is so great that it can increase purchasing power, so that it increases demand which then increases the production, 
which is one factor of economic growth of a country. Zakat management policy which is directly led by government may be able to lead into the target and even increase the social welfare. This off course is not free from clean, free from corruption and manipulation management.

One of the second Southeast Asia Zakat Board Conference (DZAT), which was held in Padang, recommendations were endorsing the formation of zakat affairs. This recommendation was welcomed by DPR by forcing the formation of DITJEN zakat. This is as a pressure of government seriousness to coordinate Islamic public finance institution management on the zakat potential. The department has a very wide rage of policy. Therefore the expectation is the existence of optimal and effective zakat acceptance.

Because in this case Indonesian people should not to long expect the welfare economically and spiritually, the urge agenda to bring that into reality is the revitalization of the role of Islamic public finance institution in Indonesia; although this agenda is considered as utopia by some Indonesia society. ${ }^{14}$

This time, the study activators on the field of Islamic public finance institution starts to develop the management concept which aims at welfare, not just to be distributed on the social and charity aspects. Ridwan al-Makasary, ${ }^{15}$ for instance, defines charity as services; Islamic public finance institution includes in the welfare philanthropy, as advocacy. In short, according to Ridwan it is "advocacy versus service". Besides, Islamic public finance institution including as welfare philanthropy it also strive for system changes (such as public policy) which do not support the welfare, and change the power relations which exist between citizen in its relationship to the government, business sector and NGO. Another important point from Islamic public finance institution as welfare philanthropy is its long term and its activity which orients at public and collective. Besides, Islamic public finance institution as

14 Darmawan Triwibowo dan Sugeng Bahagijo, Mimpi Negara Kesejahteraan, (Jakarta: Pustaka LP3ES, 2006), p. 8.

15 Research Result of PBB UIN Syarif Hidayatullah and Ford Foundation in 2003, Philantropi Untuk Keadilan Sosial: Studi Kasus Masyarakata Muslim Indonesia. 
welfare philanthropy aim at overcome social unfair structures, and also promote social change in the institutions, while charity is a short term and individual.

Al-Qur'an as a way of life, articulates the concept of philanthropy by the terms of sedekah and zakat. In the command to donate includes the ideal generosity, social justice, give each other and strengthen each other. It means that with philanthropic action, a Moslem shows one religious ethos which is not only becomes a socially correction, but also reflects a moral and spiritual values which lead to reach welfare of individual, community and society entirely. Therefore, it is not surprisingly that al-Qur'an often recommends Islam community, especially who are rich, to care for poor people. Therefore in Islamic teaching, helping orphans, poor widow, those who in debt, and those who deficit is one of high religious duties which is equal to the command of five daily prayers as religious pillar. In short, donation given to poor people is obviously horizontal worship. This donating activity is called as an Islamic philanthropy.

Islamic public finance institution in which includes Islamic philanthropy generally consists of ZIS institution and wakaf. In Islamic teaching, ZIS has the same meaning and is often used by turn, or can be changed for the similar intention as donating. The verse 60 of al-Taubah, mostly referred to as donation verse, does not introduce the term of zakat, but sedekah. However, in the discourse level the usage of zakat, infak and sedekah terms contains specific and different meaning. Zakat is often meant as spending (giving) obliged wealth and it is one of Islamic pillars, and based on a certain measurement. Infak mostly refers to gift which is not zakat, that sometime its amount is bigger that zakat. Usually it is meant to the need of fii sabilillah, means facility, such as donation for mosque, schools, Islamic boarding house and hospital. In short, donation given for community institution is included in the category of Infak. While, sedekah is usually small amount donation which is given to poor people, beggar, singing beggar etc. unequal to zakat, infak and sedekah both are highly permitted (sunnah). 
In the Indonesian context, zakat is often paid directly by muzzaki to mustahik and also collected through religious figures or mosque. This pattern of donating is traditional one, even though it is credible in the eyes of the community. However, after te $20^{\text {th }}$ century, KH Ahmad Dahlan, Muhammadiyah founder, proposed the formation of amil zakat institution, that is intermediary institution which accepts or collects zakat from muzakki and distributes it to mustahik as what has been stated in al-Taubah 60. In other word, actually the Islamic public finance institution through modern organization is not long in practice. It means that Islamic public finance institution or Islamic philanthropy organization is a modern phenomenon, although the practice of donating has been rooted in each ethnic and culture of Indonesian society. The existing donation practice is generally implemented as decentralized, not coordinated nationally, some of them may be not transparent and for different purpose and in common it is strongly motivated by the religious teaching.

Meanwhile, if we refer to authentic Prophet's hadis, then the term of wakaf (endowment) is different from zakat or sedekah. However, wakaf can be categorized as infak. In other word, the concept of infak includes wakaf. The terminology of wakat itself is not mentioned explicitly in al-Qur'an. Wakaf was born from Prophet's SAW view when He responded the question from Umar bin Khattab who wanted to give a land in Khaibar. The Prophet said, "if you like that land hold it, and donate its harvest". The history tells that the wakaf land of Umat was used for poor people, setting slaves free and neglected people. some ulama argues that wakaf implementation was firstly done by Umar bin Khattab. It means that wakaf identifies the benefit of crops, but the ownership is still maintained.

As one of Islamic philanthropy, wakaf in Muslim world has played significant role in empowering economic and social community. For example in Egypt, Jordan, Emirate Arab, and Bangladesh with professional management, then the benefit of wakaf has been taken by those who need it. In contrast, in Indonesia wakaf is not capable yet to play its role as those Moslem countries. Specifically, wakaf as one of Islamic philanthropy has been in practice since the $15^{\text {th }}$ century, when Muslim 
community especially in Java Island began to build mosque and pesantren (Islamic boarding house) as religious educational institution. In accordance to Ridwan, the orientation of wakaf as one social action must be strengthened, because the common trend of wakaf in Indonesia is for worship place/mosque (75\%), while wakaf for social purpose is very minimum, including wakaf for educational institution such as pesantren, madrasah (Islamic school), and tertiary education (university). ${ }^{16}$

Generally, there are several challenges for Islamic public finance institution to the welfare in Indonesia. First, zakat manager organizations (BAZIS and LAZIS) have not shown adequate accountability and transparency. Second, is about the reconceptualization of fikih Islamic public finance institution or modern philanthropy for example about the understanding of eight asnaf (groups), cash wakaf or productive wakaf concepts. Besides, it assumed the existence of "development" approach which is focused on the infestation in the field of infrastructure to get long term benefit than only overcoming short term problems.

\section{Conclusion}

As a final conclusion, solution for Islamic public finance institution empowerment as a welfare system in Indonesia is the work of this institution in the future, ideally, must explore creative modus in mobilizing and organizing and also facilitating the activity of Islamic public finance institution in Indonesia, to develop

the public accountability and to support initiatives of social welfare. In doing this, a welfare system is needed for Indonesian society in which contains national Islamic public finance institution and works with transparency and accountability. The institution duty is to coordinate program and ZIS and wakaf funds which up until now have not been optimally utilized because it is still decentralized in many ZIS and wakaf institutions in Indonesia. This can be understood that if ZIS and wakaf is

\footnotetext{
${ }^{16}$ Ibid.
} 
managed institutionally well, it may possibly overcome several problems of the nation.

\section{BIBLIOGRAPHY}

Abdullah, Taufik. 1991. "Zakat Collection and Distribution in Indonesia". In Muhammed Ariff (ed.). The Islamic Voluntary Sector in Southeast Asia. Singapore: Institute for Southeast Asian Studies.

Ali, Mohammad Daud. 1988. Sistem Ekonomi Islam Zakat dan Wakaf, Jakarta: Universitas Indonesia.

An-Na'im, Abdullahi Ahmed. 2003. "Filantropi untuk Keadilan Sosial Menurut Islam”. In Berderma untuk Semua. Jakarta: Pusat Bahasa dan Budaya UIN.

An-Naim, Abdullahi Ahmed and Asma Mohamed Abdel Halim. 2004. Rights-Based Approach to Philanthropy for Social Justice in Islamic Societies. Emory: Emory University.

Arinanto, Satya. 1999. "Indonesia" in Philanthropy and law in Asia. San Francisco: Jossey-Bass Publishers.

Azyumardi et al. 2003. Mencari Akar Kultural Civil Society di Indonesia. In Burhanuddin (ed). Jakarta: INCIS.

Basri, Faisal. 2002. Perekonomian Indonesia, Tantangan dan Harapan bagi Kebangkitan Indonesia. Jakarta: Erlangga.

Baswir, Revrisond. 2004. "Problematika LSM di Indonesia" in Hamid Abidin and Mimin Rukmini (eds.). Kritik dan Otokritik LSM: Membongkar Kejujuran dan Keterbukaan Lembaga Swadaya Masyarakat Indonesia. Jakarta: PIRAC, Ford Foundation and Tifa.

Chaniago, Andrinof A. 2001. Gagalnya Penbangunan, Kajian Ekonomi Politik Terhadap Akar Krisis Indonesia. Jakarta: LP3ES.

Chapra, Muhammad Umar. "Tujuan Tata Ekonomi Islam” in Khursid Ahmad (ed.). Pesan Islam. Bandung: Pustaka, 1983.

Coulson, N.J. 1994. A History of Islamic Law, Edinburgh: Edinburgh University Press.

Dirjen Bimbingan Islam dan Penyelenggaraan Haji. 2003. Peraturan Perundangundangan Pengelolaan Zakat. Jakarta: Dirjen Bimbingan Islam dan Penyelenggaraan Haji.

Dumairi. 1996. Perekonomian Indonesia. Jakarta: Penerbit Erlangga. 
Ecip, S. Sinansari. 2003. Jejak-Jejak Membekas 10 Tahun Dompet Dhuafa Republika, Jakarta: Cahaya Timur.

Eri Sudewo. "Mengkritisi UU Zakat”. Republika 23/05/2003.

Esposito, John L. and Francois Burgat (eds.). 2003. Modernizing Islam: Religion in the Public Sphere in Europe and the Middle East. New Jersey: Rutgers University Press.

Hafidhuddin, Didin. 1998. Panduan Praktis tentang Zakat, Infak dan Sedekah. Jakarta: Gema Insani. . 2002. Zakat dalam Perekonomian Moderen. Jakarta: Gema Insani Press.

Hamid, Edy Suandi,2006, Ekonomi Indonesia: Dari Sentralisasi ke Desentralisasi, Yogyakarta: UII Press

Hasanah, Uswatun. 1997. Peranan Wakaf dalam Mewujudkan Kesejahteraan Sosial: Studi Kasus Pengelolaan Wakaf di Jakarta Selatan. Dissertation of PostGraduate Program IAIN Syarif Hidayatullah. Jakarta.

Hooker, M.B.. 2003. "The State and Shari'a in Indonesia”. In Arskal Salim and Azyumardi Azra (eds.). Shari'a and Politics in Modern Indonesia. Singapore: ISEAS.

Juoro, Umar. 1990. "Persaingan Global dan Ekonomi di Indonesia Dekade 1990-an". Prisma. No. 8. Tahun XIX. Jakarta: LP3ES.

Karim, Adiwarman A, 2007, Ekonomi Mikro Islam, Jakarta: PT Raja Grafindo Persada

Kompas, 20 March 2004.

21 September 2003.

Lembaga Penelitian UIN Syahid. 2002. "Respon Institusi Pengelola Zakat Terhadap Efektivitas Undang-Undang No 38 tahun 1999".

Madjid, Nurcholish. 1984. Islam Kemodernan dan Keindonesiaan. Bandung: Penerbit Mizan.

1992. Islam Doktrin dan Peradaban: Sebuah Telaah Kritis tentang Masalah Keimanan, Kemanusiaan, dan Kemodernan, Jakarta: Penerbit Paramadina.

Mas'oed, Muhtar. 1994. Politik, Birokrasi dan Pembangunan. Yogyakarta: Pustaka Pelajar.

McChesney, R. D.. 2002. Charity and Philanthropy in Islam: Institutionalizing the Call to Do Good. Indianapolis: The Trustees of Indiana University, Indiana. 
PIRAC, 2002. Membangun Kemandirian Berkaya, Potensi dan Pola Derma, serta Penggalanganya di Indonesia. Jakarta: PIRAC.

Rahardjo, M. Dawam. 1991. Perspektif Deklarasi Mekah, Menuju Ekonomi Islam. Bandung: Mizan.

Rahman, Fazlur. 1970. "Islamic Modernism: Its Scope, Method and Alternatives". In International Journal of Middle East Studies. Volume 1. . 1982. Islam and Modernity, Transformation of an Intellectual Tradition. Chicago: The University of Chicago Press

Republika. "Sosialisasi UU Zakat". 14/07/2003.

Sabra, Adam. 2000. Poverty and Charity in Medieval Islam (Mamluk Egypt, 12501517). United Kingdom: Cambridge University Press.

Saeed, Abdullah. 2004. Menyoal Bank Syariah: Kritik atas Interpretasi Bunga Bank Kaum Neo-Revivalis. Translated from Islamic Banking and Interest: A Study of Riba and Its Contemporary Interpretation. Jakarta: Penerbit Paramadina.

Saidi Zaim. 2003. "Peluang dan Tantangan Filantropi Islam di Indonesia" in Idris Thaha (ed.), Berderma untuk Semua, Wacana dan Praktik Filantropi Islam, Jakarta: Ford Foundation, Pusat Bahasa dan Budaya UIN Jakarta, and Teraju.

Saidi, Zaim, Hamid Abidin and Kurniawati (eds.). 2002. Membangun Kemandirian Berkarya: Potensi dan Pola Derma, serta Penggalangan di Indonesia. Jakarta: PIRAC and Ford Foundation.

Salim, Arskal. 2000. Pengelolaan Zakat Dalam Politik Orde Baru. Research Report by Puslit IAIN Syarif Hidayatullah.

. 2003. "Zakat Administration in Politics of Indonesian New Order". In Arskal Salim and Azyumardi Azra (eds.), Shari'a and Politics in Modern Indonesia. Singapore: ISEAS.

Suhadi, Imam, Dr. H. SH. Wakaf Untuk Kesejahteraan Umat. Yogjakarta: PT Dhana Bhakti Prima Yasa.

Swasono, Sri-Edi. 1987. Pandagan Islam dalam Sistem Ekonomi Indonesia. Jakarta: UI Press.

Triwibowo, Darmawan, dan Sugeng Bahagijo. 2006. Mimpi Negara Kesejahteraan, Jakarta: LP3ES

Usman, H. Suparman, Drs. SH. 1999. Hukum Perwakafan di Indonesia. Jakarta: Darul Ulum Press. 